\title{
ANALISIS FAKTOR KEHADIRAN DOSEN DI UNIVERSITAS X
}

\author{
Annisa Mulia Rani \\ Program Studi Teknik Industri \\ Universitas Muhammadiyah Jakarta \\ Zc.annisa@gmail.com
}

\begin{abstract}
Abstrak
Aspek kualitas pekerjaan berkaitan langsung dengan waktu yang khusus digunakan dosen untuk mengembangkan kemampuan. Maka untuk merealisasikan kualitas dosen yang terbaik, pihak manajemen khusunya dekan membuat peraturan untuk kehadiran dosen adalah minimal 25 jam/minggu. Dengan peraturan ini diharapkan dosen dapat melaksanakan beban kerja dosen sebaik-baiknya. Peraturan ini tertulis dan tertuang pada SK Dekan No 20/2006 pada kampus X. Dengan Menggunakan Analisis faktor mencoba menemukan hubungan atar sejumlah variable-variabel yang awalnya saling independen satu dengan yang lain dimana variable penyebab kekurangan jam dosen datang/minggu adalah keluaraga, manajemen, hubungan social, fasilitas pengajaran, jarak/lokasi, kompensasi transport. Berdasarkan uji Bartley test dan Measure sample of adequate yang pertama maka dengan nilai sig 0.04 dan msa 0.540 . Dengan menggunakan metode principal component analysis maka pembentukan factor hanya ada 1 componen karena nilai eigen value yang mempunyai nilai diatas 1. Faktor pembentuk baru yaitu manajemen, kompensasi dan jarak menjadi satu component.
\end{abstract}

Kata kunci : Analisis factor, Principal component analysis.

\section{PENDAhUluAN}

Kinerja dosen pada suatu perguruan tinggi merupakan perilaku nyata yang ditampilkan setiap dosen sebagai prestasi kerja yang dihasilkan oleh dosen tersebut sesuai dengan peranannya.Untuk dapat menentukan kualitas kinerja dosen perlu adanya criteria yang jelas. Sondang menyatakan bahwa kinerja meliputi beberapa aspek, yaitu: aspek kualitas pekerjaan, ketepatan waktu, prakarsa, kemampuan dan komunikasi

Aspek kualitas pekerjaan berkaitan langsung dengan waktu yang khusus digunakan dosen untuk mengembangkan kemampuan. Maka untuk merealisasikan kualitas dosen yang terbaik, pihak manajemen khusunya dekan membuat peraturan untuk kehadiran dosen adalah minimal $25 \mathrm{jam} / \mathrm{minggu}$. Dengan peraturan ini diharapkan dosen dapat melaksanakan beban kerja dosen sebaik-baiknya. Peraturan ini tertulis dan tertuang pada SK Dekan No 20/2006 pada kampus X

Dengan peraturan untuk kehadiran dosen minimal 25 jam/minggu ini melalui studi pendahuluan $\mathrm{t}$ bahwa untuk setiap dosen-dosen yang ada tidak memenuhi standar dari kehadiran dosen minimal $25 \mathrm{jam} /$ minggu dan tidak memenuhi peraturan yang telah dibuat oleh dekan. Untuk itu diperlukan suatu penelitian lebih lanjut untuk menganalisa dan mencari faktor penyebab atas kekurangan dari jam standart $25 \mathrm{jam} / \mathrm{minggu}$.

\section{LANDASAN TEORI}

\section{A. Kepuasan Kerja Karyawan}

Sondang (1998) menunjukkan bahwa terdapat 6 faktor penting yang mempengaruhi kepuasan kerja karyawan yaitu:

1. Pekerjaan itu sendiri Unsur ini menjelaskan pandangan karyawan mengenai pekerjaannya yang menarik, melalui pekerjaan tersebut karyawan memperoleh kesempatan untuk belajar dan memperoleh peluang untuk menerima tanggung jawab

2. Kompensasi

Para karyawan menginginkan sistem upah dan kebijakan promosi yang mereka persepsikan sebagai adil yang didasarkan pada tuntutan pekerjaan, tingkat 
ketrampilan individu dan standar pengupahan komunitas, kemungkinan besar akan dihasilkan kepuasaan

3. Kesempatan promosi

Kesempatan promosi mengakibatkan pengaru yang berbeda terhadap kepuasan kerja karena adanya perbedaan balas jasa yang diberikan. Dengan demikian promosi akan selalu diikuti oleh tugas, tanggung jawab dan wewenang yang lebi tinggi dari jabatan yang diduduki sebelumnya.

4. Supervisi

Tugas pengawasan tidak dapat dipisahkan dengan funsi kepemimpinan yaitu usaha mempengarui kegiatan bawaan melalui proses komunikasi untuk mencapai tujuan yang sudah ditetapkan oleh oganisasi

5. Rekan kerja

Rekan kerja yang bersahabat, kerjasama rekan sekerja atau kelompok kerja adalah sumber kepuasan kerja bagi pekerja secara individual.Sementara kelompok kerja dapat memberikan dukungan, nasihat, bantuan kepada sesame rekan kerja. Kelompok kerja yang baik membuat pekerjaan lebih menyenangkan.

6. Kondisi kerja

Apabila kondisi kerja bagus (lingkungan yang bersih dan menarik), akan

Membuat pekerjaan dengan mudah ditangani. Sebaliknya jika kondisi kerja

tidak menyenangkan akan berdampak sebaliknya.

\section{B. Analisis Faktor}

Analisis faktor mencoba menemukan hubungan atar sejumlah variable-variabel yang awalnya saling independen satu dengan yang lain, seingga bisa dibuat satu atau beberapa kumpulan variable yang lebih sedikit dari jumlah variable awal

1. Kegunaan Analisis Faktor

a. Untuk mengidentifikasi underlying dimensions (faktor) yang dapat menjelaskan korelasi sekumpulan variabel.

b. Untuk mengidentifikasi variabel baru, yang dapat digunakan untuk analisislainnya

c. Untuk mengidentifikasi satu atau beberapa variabel dari variabel yang banyak jumlahnya.

d. Mengkonfirmasi kontruksi suatu variabel laten.

A. Proses Dasar Analisis Faktor

a. Menetukan variable apa saja yang akan dianalisis

b. Menguji variable-variabel yang telah ditentukan pada langkah 1 diatas untuk menetukan variable variable yang dapat dianggap layak untuk masuk tahap analisis faktor, pengujian menggunakan metode Bartlett test of speheriicity serta pengukuran Measure of Smapling adequacy

c. Setelah sejumlah variable yang memenuhi syarat didapat, kegiatan berlanjut ke proses inti pada analisisbfaktor yakni faktoring: proses ini akan mengekstrak satu atau lebih faktor atau variable-variabel yang telah lulus pada uji variable sebelumnya.

d. Interpretasi atas faktor yang terbentuk tersebut, yang bisa dianggap mewakili variable-variabel anggota faktor tersebut

e. Validasi atas hasil faktor

\section{Metode Analisis Faktor}

\section{Principal Component Analysis}

Pada metode ini bertujuan utama untuk mereduksi data dan beranggapan bahwa jumlah specific variance dan error variance berjumlah kecil.Metode ini biasa juga disebut metode eksploratori. 


\section{Metode common Analysis}

Pada metode ini dibuat sejumlah faktor yang akan dibentuk, serta variabel apa saja yang termasuk ke dalam masing-masing faktor yang dibentuk dan sudah pasti tujuannya. Metode ini hanya berhubungan dengan common variance.

\section{Proses-proses dalam menganalisis faktor-faktor yaitu:}

a. Rotate Faktors (Melakukan Rotasi terhadap Faktor). Hasil penting analisis faktor adalah matriks faktor, yang disebut juga faktor pattern matrix (matrik pola faktor), berisi koefisien yang digunakan untuk menunjukkan variabelvariabel yang distandarisasi dalam batasan sebagai faktor. Didalam suatu matriks yang kompleks sulit menginterpretasikan suatu faktor. Oleh karena itu, melalui rotasi matriks, faktor ditransformasikan ke dalam bentuk yang lebih sederhana yang lebih mudah

b. yang diperhitungkan untuk setiap faktor tidak berubah. Variance yang dijelaskan oleh faktor individual diredistribusikan melalui rotasi. Perbedaan metode rotasi akan menghasilkan identifikasi faktor yang berbeda. Metode yang digunakan untuk rotasi adalah varimax procedure,.yang meminimalkan banyaknya variabel dengan loading tinggi pada faktor, sehingga meningkatkan kemampuan menginterpretasikan faktor-faktor yuntuk diinterpretasikan, dengan harapan setiap faktor memiliki nilai non zero (tidak 0) atau signifikan.

c. Select Surrograte Variables (Memilih Variabel-variabel Pengganti). Memilih variabel pengganti sehingga peneliti dapat melaksanakan analisis berikutnya dan menginterpretasikan hasil dalam batasan variabel semula daripada skor faktor dengan menguji matriks faktor dan memilih setiap faktor variabel yang memiliki loading paling tinggi pada faktor tersebut.

d. Determine Model Fit (Menetapkan Model yang Sesuai). Langkah akhir dalam analisis faktor adalah penentuan ketepatan model. Perbedaan antara korelasi yang diamati (yang terdapat dalam input matriks korelasi) dan korelasi yang dihasilkan kembali (seperti yang diestimasikan pada matriks faktor) dapat diuji melalui model itu sendiri, yang disebut residual. Jika terdapat banyak residual yang besar, maka model faktor kurang tepat dan model perlu dipertimbangkan kembali

\section{METODE PENELITIAN}

Adapun metodologi penelitian yang dilakukan adalah:

1. Penelitian Pendahuluan

Penelitian pendahuluan ini adalah dengan merekap kehadiran dosen dosen selama seminggu dari bulan Maret 2014 sampai Juli 2014.

2. Perumusan masalah

Melalui penelitian pendahuluan diketaui hamper kesleruhan dari dosen teknik industry tidak memenui ketentuan dari peraturan dekan dengan SK NO 20 tahun 2006 yang mewajibkan kehadiran di kampus selama 25 jam/minggu.

3. Tujuan Penelitian

Tujuan penelitian adalah untuk mengetahui faktor faktor yang berpengaruh dan menganalisa faktor yang dominan terhadap kekurangan kehadiran dosen selama 25 $\mathrm{jam} /$ minggu

4. Pengumpulan Data

Data yang dikumpulkan terdiri dari data primer yaitu berupa data kuesioner dosen, dan untuk data sekunder berupa rekapan data absen dosen.

5. Pengujian dan Pengolahan Data

Data yang telah didapat diuji secara dan diolah secara statistik dengan menggunakan software SPSS 16.00.dimana pengujian dengan mengajukan hipotesis awal jika 
Ho : sampel (variabel) belum memadai untuk dianalisis lebih lanjut

H1 : sampel (variabel) sudah memadai untuk dianalisis lebih lanjut

Dimana Sig > 0,05, maka Ho diterima dan jika Sig < 0,05, maka Ho ditolak

kemudian melakukan uji dan pengujian barttley test dengan menggunakan angka MSA

(Measure of Sampling Adequacy), yaitu berkisar 0 sampai 1 dengan kriteria :

a. $\mathrm{MSA}=1$; variabel tersebut dapat diprediksi tanpa kesalahan oleh variabel lain lanjut, atau harus dikeluarkan dari variabel lainnya

b. MSA $>0,5$ variabel masih bisa diprediksi dan bisa dianalisis lebih lanjut

c. MSA $<0,5$ variabel tidak dapat diprediksi dan tidak dapat dianalisis lebih lanjut

6. Analisa Pengolahan Data

Analisa dapat dilakukan setelah data diolah sehingga dapat mennetukan faktor-faktor yang berpengaruh terhadap kekurangan kehadiran selama 25 jam/minggu .

7. Kesimpulan dan saran

Setelah didapat hasil dari analisis faktor kekurangan kehadiran dosen selama 25 $\mathrm{jam} /$ minggu dapat menentukan faktor penentu dari permasalahan ini dan bisa memberikan masukan kepada pihak manajemen.

\section{HASIL DAN PEMBAHASAN}

\section{A. Pengumpulan Data}

\section{Pengumpulan Data Kehadiran Dosen}

Pengumpulan data dengan mengumpulkan data absensi dosen-dosen jurusan Teknik Industri dari bulan Maret 2014 sampai dengan 31 Juli 2014 kemudian data diolah dengan menggunakan ketentuan dekan yaitu jam masuk dari jam 07.00 WIB - 17.00 WIB dari hari Senin sampai Jumat. (data diperoleh dari pihak admistrasi fakultas)

\section{Pengumpulan Data Kuesioner}

Pada pengumpulan data tahap ini, kuesiner disebarkan kepada para dosen di lingkungan kampus $\mathrm{x}$. Kuesioner ini menggunakan skala likert dengan penilaian dapat dilihat pada tabel dibawah ini:

Tabel 1. Bobot Penilaian Kuesioner

\begin{tabular}{|l|l|}
\hline Penilaian & Bobot Penilaian \\
\hline Sangat tidak setuju & 1 \\
\hline Tidak Setuju & 2 \\
\hline Biasa & 3 \\
\hline Setuju & 4 \\
\hline Sangat Setuju & 5 \\
\hline
\end{tabular}

Kuesioner ini berisi faktor-faktor penyebab terhadap kekurangan kehadiran dosen 25 jam/minggu.Kuesioner ini diisi oleh dosen yang kekurangan kehadiran 25 jam/minggu.Sedangkan dosen yang memenuhi kewajiban tersebut tidak mengisi kuesioner. 
Tabel 2. Kuesioner Faktor-Faktor Penyebab Kekurangan Kehadiran Mengajar 25 Jam/Minggu

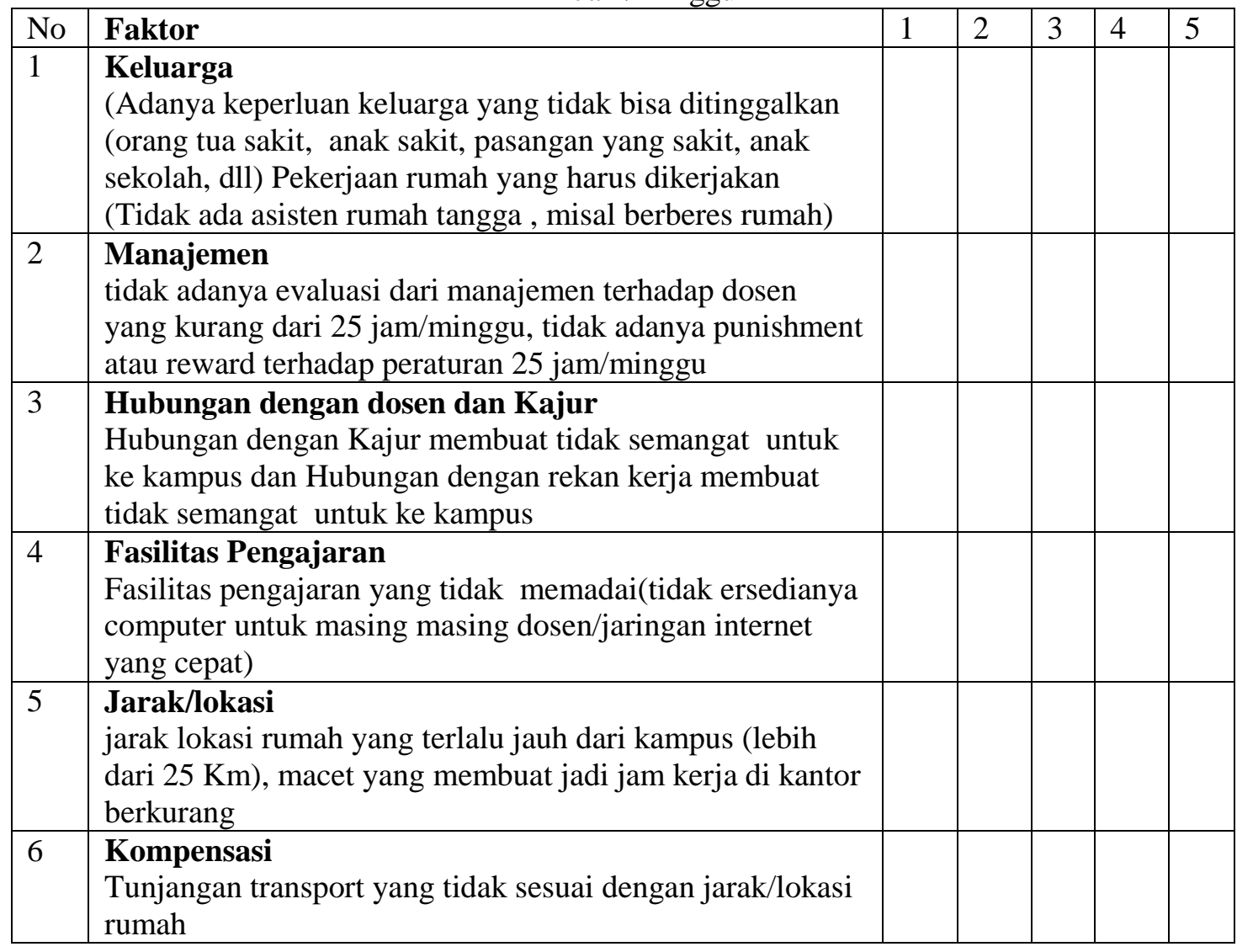

\section{B. Pengolahan Data dan Analisa}

1. Pengolahan Data Absensi

Berdasarkan SK Dekan no 20/2006 yang menetapkan hari dan jam kerja yaitu hari Senin sampai Jumat dari Jam 08.00 WIB -16.00 WIB dan mendapat dispensasi \pm 1 jam sebelum dan sesudah sehingga pencatatan akumulasi jam kerja dari jam 07.00 WIB - 17.00 WIB. Adapun rekapitulasi jumlah jam kerja dosen jurusan Teknik Industri sapat jika ditotal secara keseluruhan dosen-dosen didapat waktu rata-rata dosen hadir/minggu adalah 19,5 jam/minggu.

2. Pengolahan Data daan Analisa Kuesioner

Hasil kumpulan data yang terisi dapat dilihat pada lampiran, kemudian data dimasukkan ke program SPSS 16.0 seperti gambar di bawah ini :

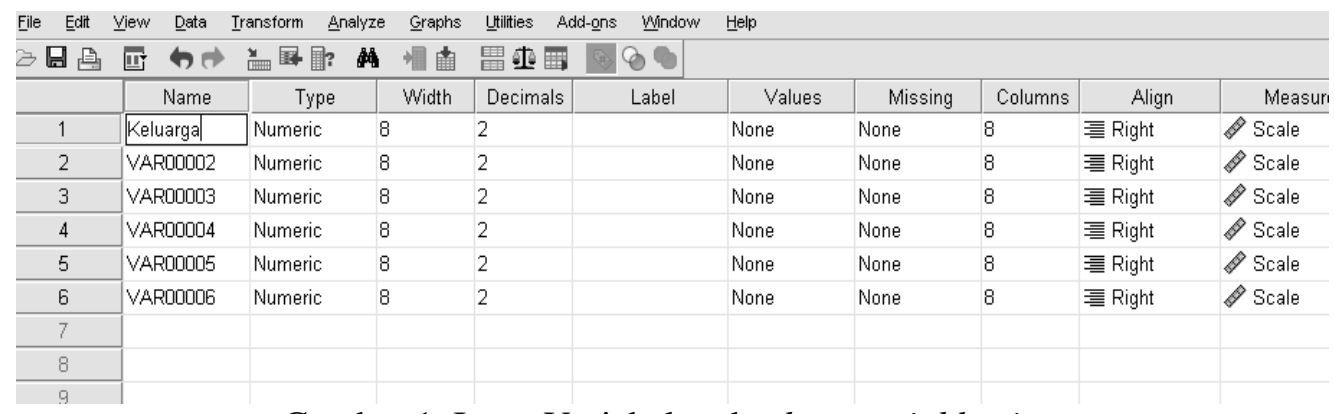

Gambar 1. Input Variabel pada sheet variable view 
Dan untuk data view dapat dilihat pada gambar 2.

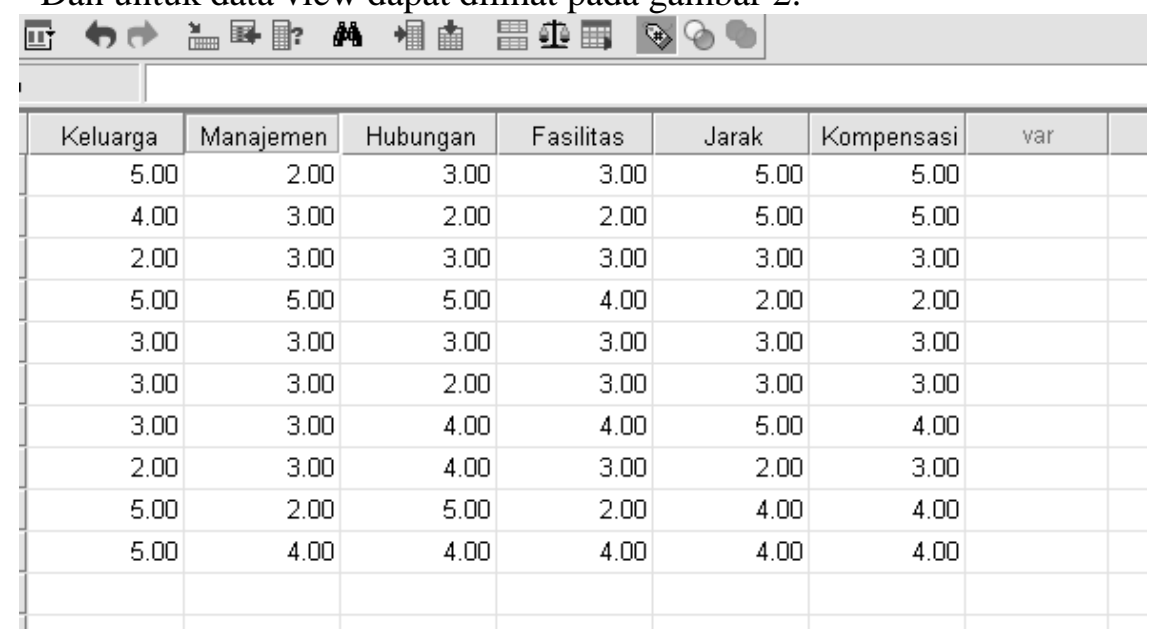

Gambar 2. Data View

Kemudian lakukan analisa dengan analyze dan reduksi seperti gambar dibawah ini

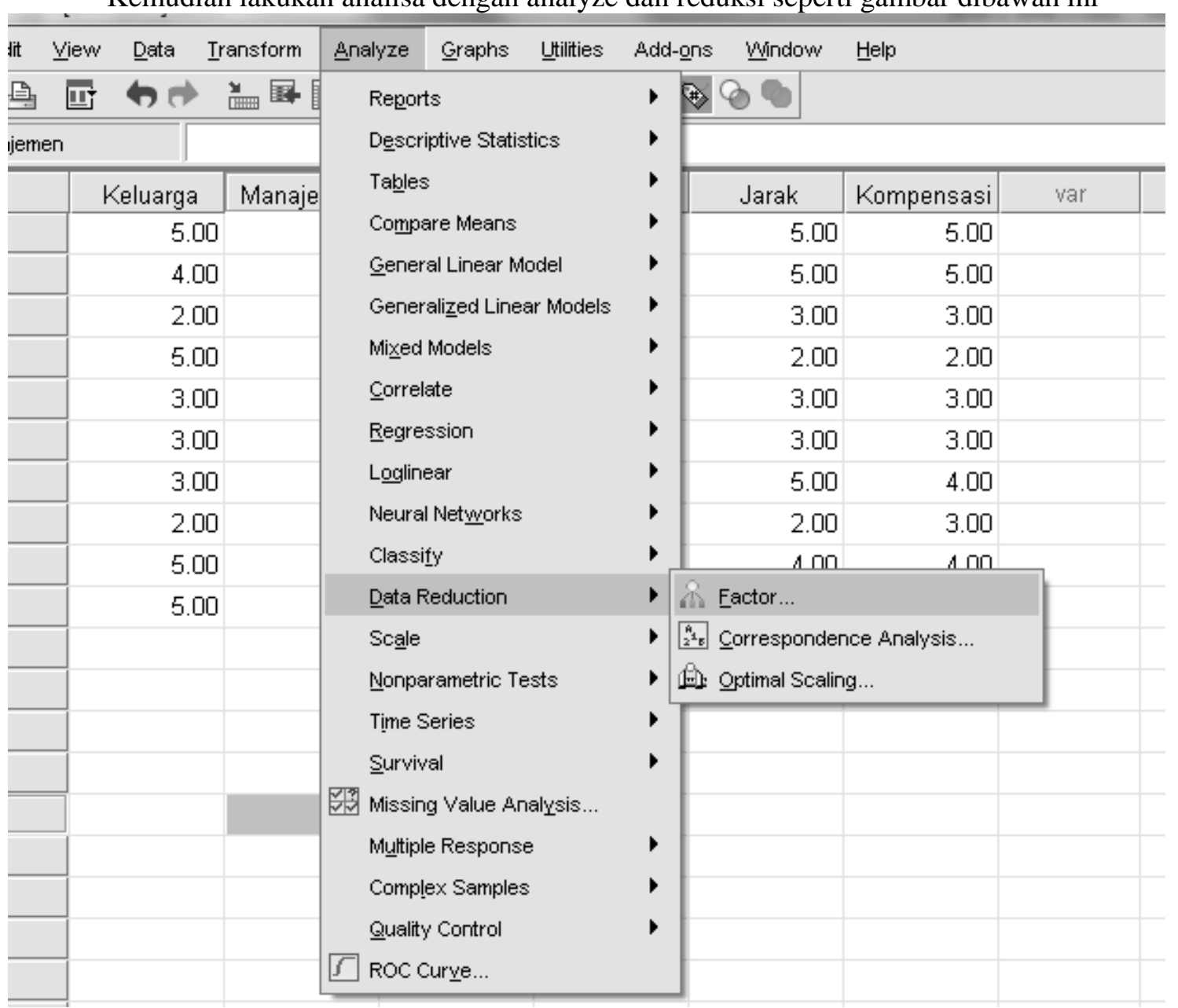

Gambar 3. Data Reduction, Faktor 
Kemudian akan tampak perintah seperti gambar dibawah ini:

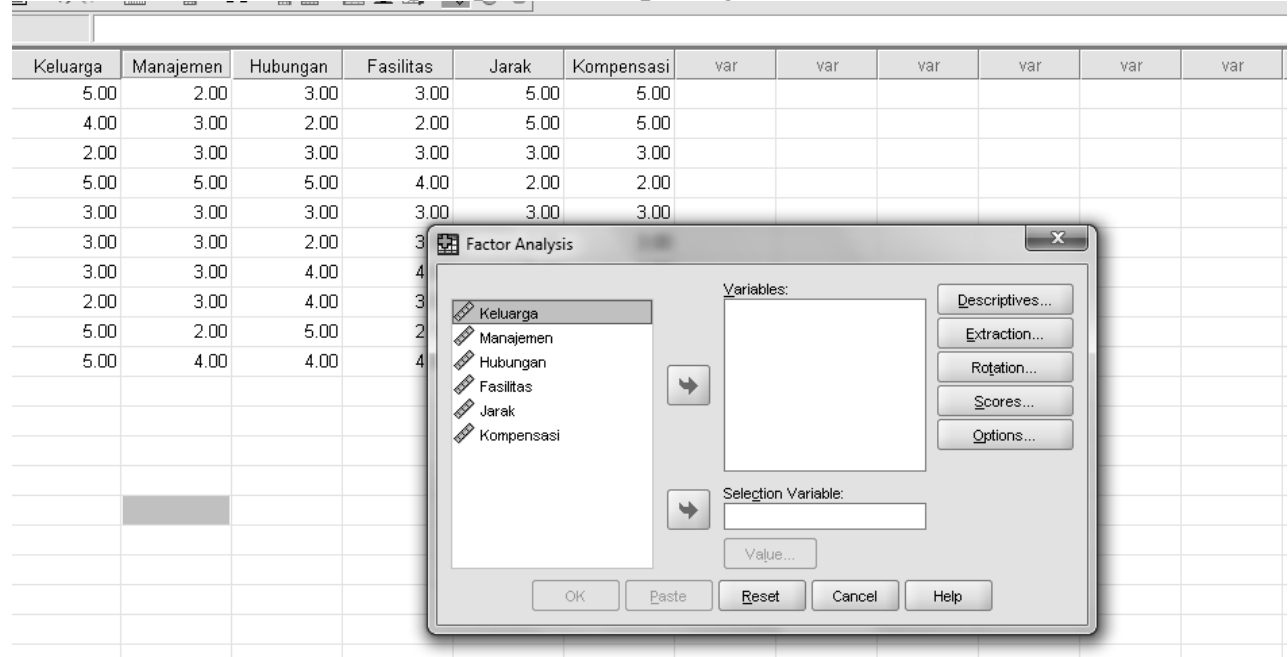

Gambar 4. Factor analysis

Kemudian pindahkan variable yang akan diuji dan direduksi pada kolom variable (gambar 5)

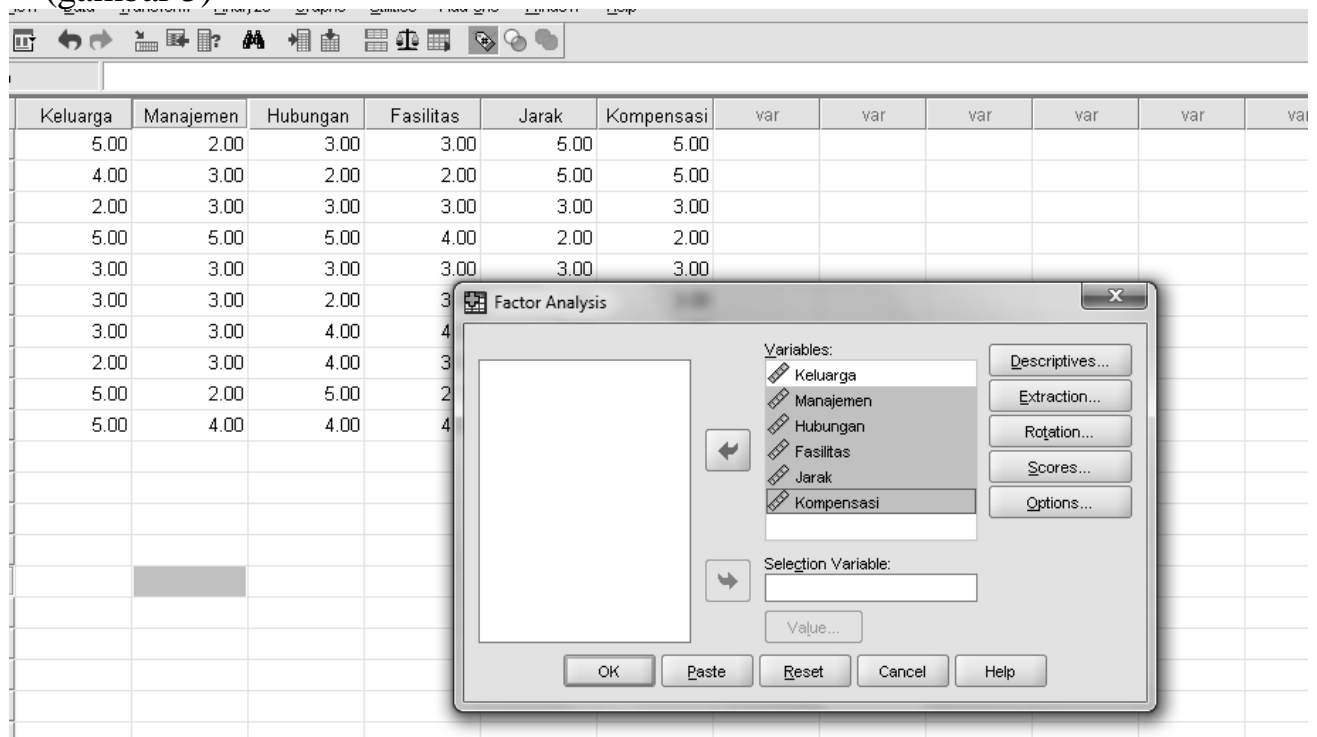

Gambar 5. Pemasukan variable yang akan diuji 
Setelah itu klik descriptive dan klik KMO and Bartlley test of sphericity dan klik anti image, maka akan terlihat seperti di gambar 6.

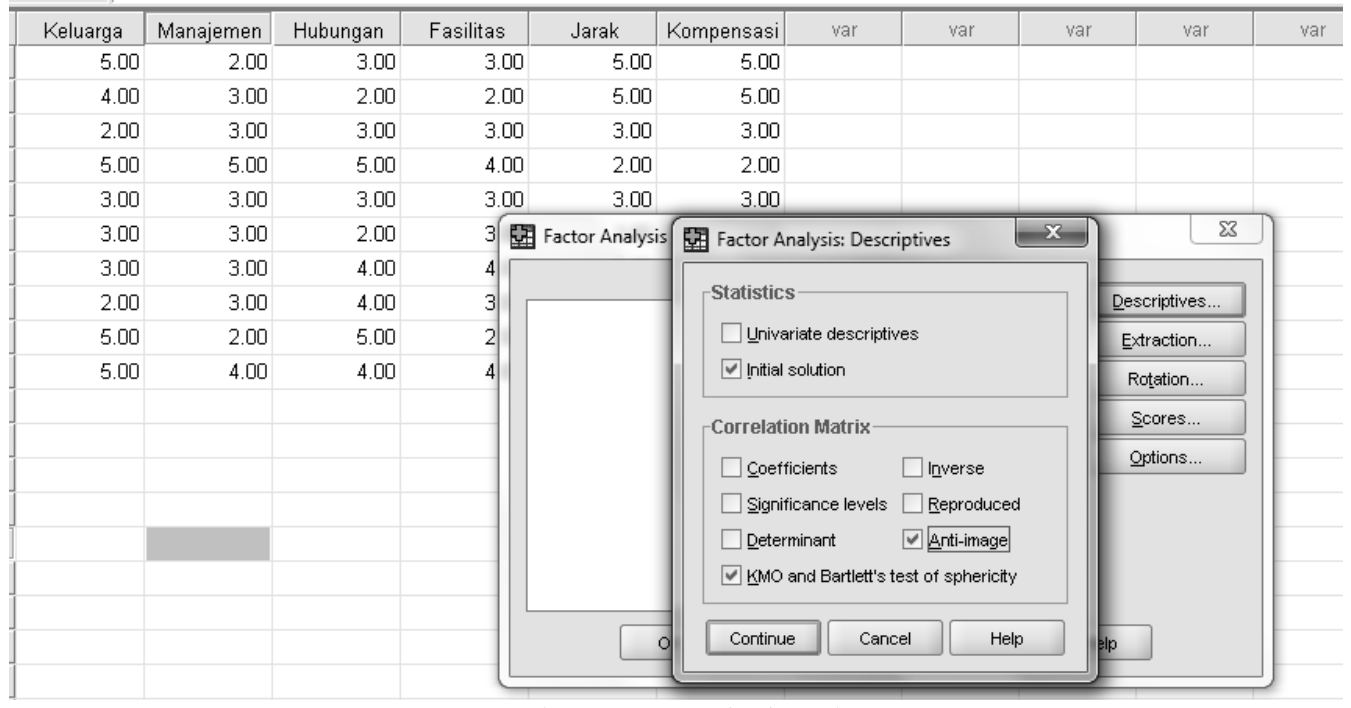

Gambar 6. Descriptive data

Setelah itu klik continue dan ok maka akan terlihat di output SPSS seperti pada Tabel Uji Data KMO and Bartlett's Test

Tabel Uji Data KMO and Bartlett's Test

KhiO and Bartlett's Test

\begin{tabular}{|c|c|c|}
\hline \multicolumn{2}{|c|}{ Kaiser-Meyer-Olkin Measure of Sampling Adequacy. } & 540 \\
\hline $\begin{array}{l}\text { Bartlett's Test of } \\
\text { Sphericity }\end{array}$ & $\begin{array}{l}\text { Approx. Chi-Square } \\
\text { df } \\
\text { Sig. }\end{array}$ & $\begin{array}{r}25.779 \\
15 \\
.040\end{array}$ \\
\hline
\end{tabular}

Berdasarkan pengujian tahap awal maka diperoleh measure of sampling adequacy adalah

0,540 maka dengan nilai MSA > 0.5 maka variabel masih bisa diprediksi dan bisa dianalisis

lebih lanjut. Dan dengan pengajuan hipotesis awal yaitu :

Ho : sampel (variabel) belum memadai untuk dianalisis lebih lanjut

H1 : sampel (variabel) sudah memadai untuk dianalisis lebih lanjut

Dimana Sig $>0,05$, maka Ho diterima dan jika Sig $<0,05$, maka dengan signifikan 0,04

H1 dapat diterima.

Dan dari hasil Output didapat sebagai berikut: 
Tabel 3. Anti Image Matrices

Anti-image Matrices

\begin{tabular}{|ll|r|r|r|r|r|r|}
\hline & & Keluarga & Manajemen & Hubungan & Fasilitas & \multicolumn{1}{c|}{ Jarak } & Kompensasi \\
\hline Anti-image Covariance & Keluarga & .449 & -.191 & -.291 & .115 & -.028 & -.053 \\
& Manajemen & -.191 & .301 & .130 & -.207 & .031 & .035 \\
& Hubungan & -.291 & .130 & .551 & -.151 & .027 & .041 \\
& Fasilitas & .115 & -.207 & -.151 & .386 & -.097 & .057 \\
& Jarak & -.028 & .031 & .027 & -.097 & .114 & -.088 \\
& Kompensasi & -.053 & .035 & .041 & .057 & -.088 & .095 \\
\hline Anti-image Correlation & Keluarga & $.347^{2}$ & -.518 & -.586 & .277 & -.125 & -.254 \\
& Manajemen & -.518 & $.591^{2}$ & .320 & -.606 & .166 & .204 \\
& Hubungan & -.586 & .320 & $.463^{2}$ & -.328 & .108 & .179 \\
& Fasilitas & .277 & -.606 & -.328 & $.476^{\mathrm{z}}$ & -.464 & .298 \\
& Jarak & -.125 & .166 & .108 & -.464 & $.577^{\mathrm{z}}$ & -.844 \\
& Kompensasi & -.254 & .204 & .179 & .298 & -.844 & $.630^{\mathrm{a}}$ \\
\hline
\end{tabular}

a. Measures of Sampling Adequacy(MSA)

Berdasarkan hasil SPSS untuk nilai Measures of sampling Adequacy (MSA) yang akan dikeluarkan dari proses adala yang dibawah 0,5. Dari tabel variable yang dibawah 0,5 ada variable keluarga (0.347), variable hubungan (0.463), variable fasilitas (0.476). maka setelah ini dilakukan pengujian ulang kembali

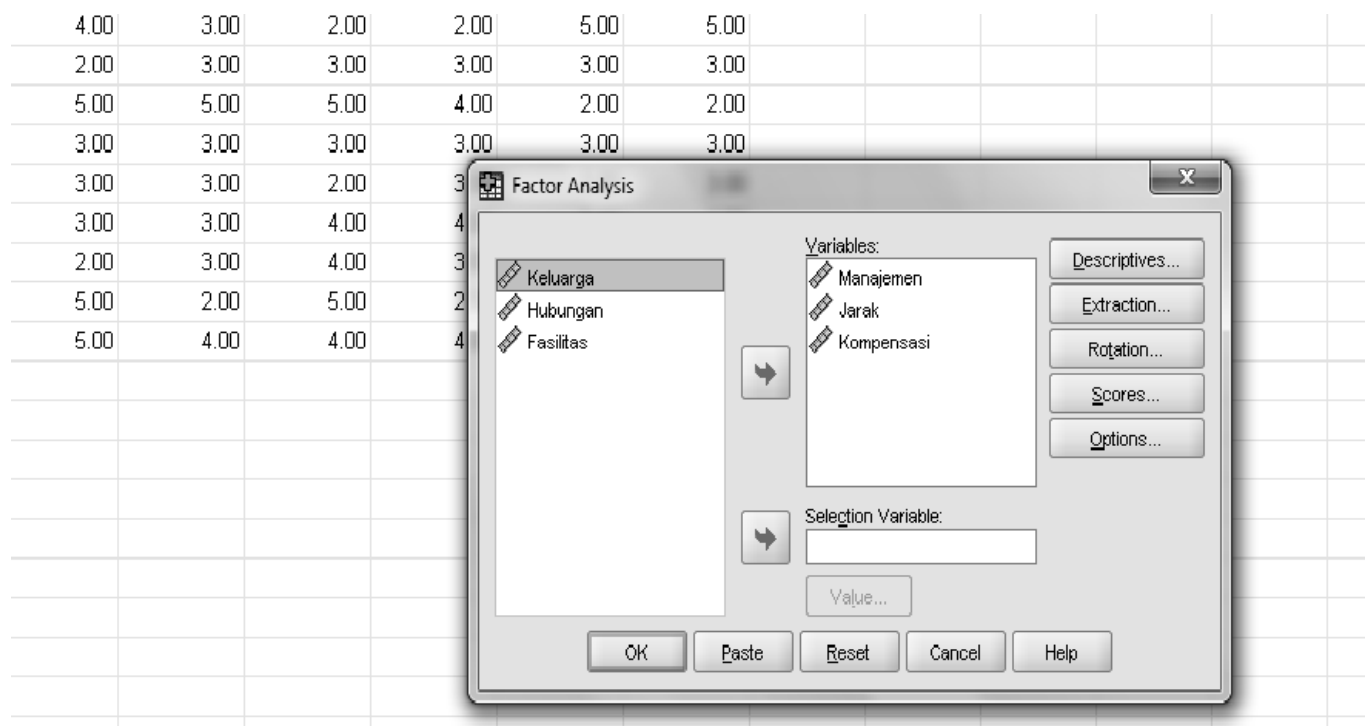

Gambar 7. Pengujian Kembali (Membuang variable Keluarga,,Hubungan,Fasilitas) 
Setelah itu klik descriptive dan klik KMO and Bartlley test of sphericity dan klik anti image, maka akan terlihat seperti di gambar 8.

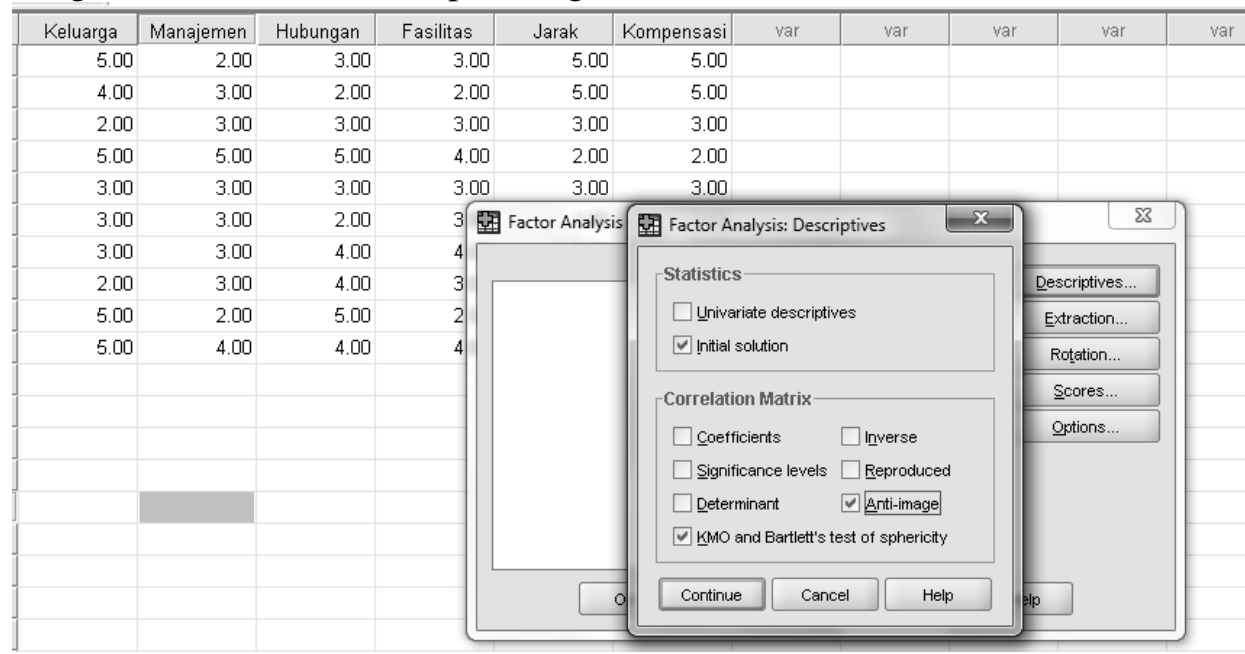

Gambar 8 Descriptive Data Ke Dua

Adapun hasil dari pengujian kedua ini dengan membuang variable keluarga, hubungan, dan fasilitas adalah sebagai berikut:

Tabel 4. Uji Data KMO and Bartlett's Test ke Dua

KHO and Bartlett's Test

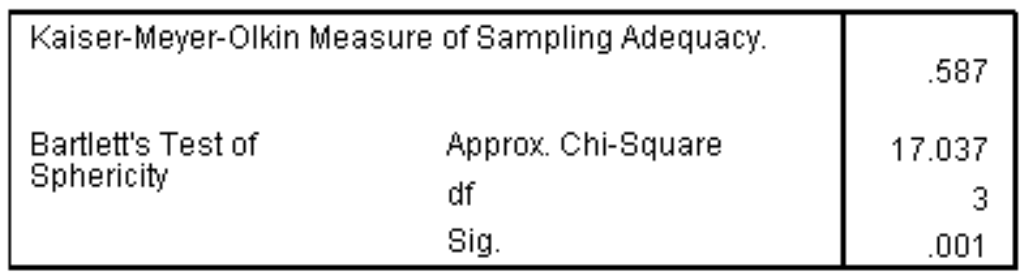

Berdasarkan pengujian proses kedua maka diperoleh measure of sampling adequacy adalah 0,587 maka dengan nilai MSA > 0.5 maka variabel masih bisa diprediksi dan bisa dianalisis lebih lanjut.dan nilai MSA kedua ini lebih tinggi jika dibandingkan tahap pertama. Dan dengan pengujian kedua jika Sig $<0,05$ dapat diterima, maka dengan signifikan 0,001 maka variable dapat dilanjutkan.

Dan hasil output pada tahap 2 dapat dilihat pada tabel 5.

Tabel 5. Anti Image Matrices ke Dua

\section{Anti-image Matrices}

\begin{tabular}{|ll|r|r|r|}
\hline & & Manajemen & Jarak & Kompensasi \\
\hline Anti-image Covariance & Manajemen & .612 & -.057 & .119 \\
& Jarak & -.057 & .146 & -.121 \\
& Kompensasi & .119 & -.121 & .123 \\
\hline Anti-image Correlation & Manajemen & $.733^{2}$ & -.191 & .433 \\
& Jarak & -.191 & .565 & -.898 \\
& Kompensasi & .433 & -.898 & $.550^{\mathrm{a}}$ \\
\hline
\end{tabular}

a. Measures of Sampling Adequacy(MSA) 
Dari tabel diatas dapat dilihat nilai MSA yang bertanda huruf a adalah diatas 0.5 semuanya, yaitu masing-masing variable untuk manajemen 0.733 , variable jarak 0.565 dan untuk variable kompensasi 0.550

Kemudian lanjutkan pada tahap kedua Analisis factor yaitu proses factoring dan rotasi, pada tahap ini melakukan ekstrasi terhadap sekumpulan variable, sehingga terbentuk satu atau lebih factor. Adapun prosesnya yaitu klik analyze lalu dimension redection dan klik exctraction pilih principal component dan correlation matrix, dan display aktifkan unrotated factor solution serta scree plot dengan eigen value adalah 1 dan maximum iterations for convergence adalah 25 (gambar 9)

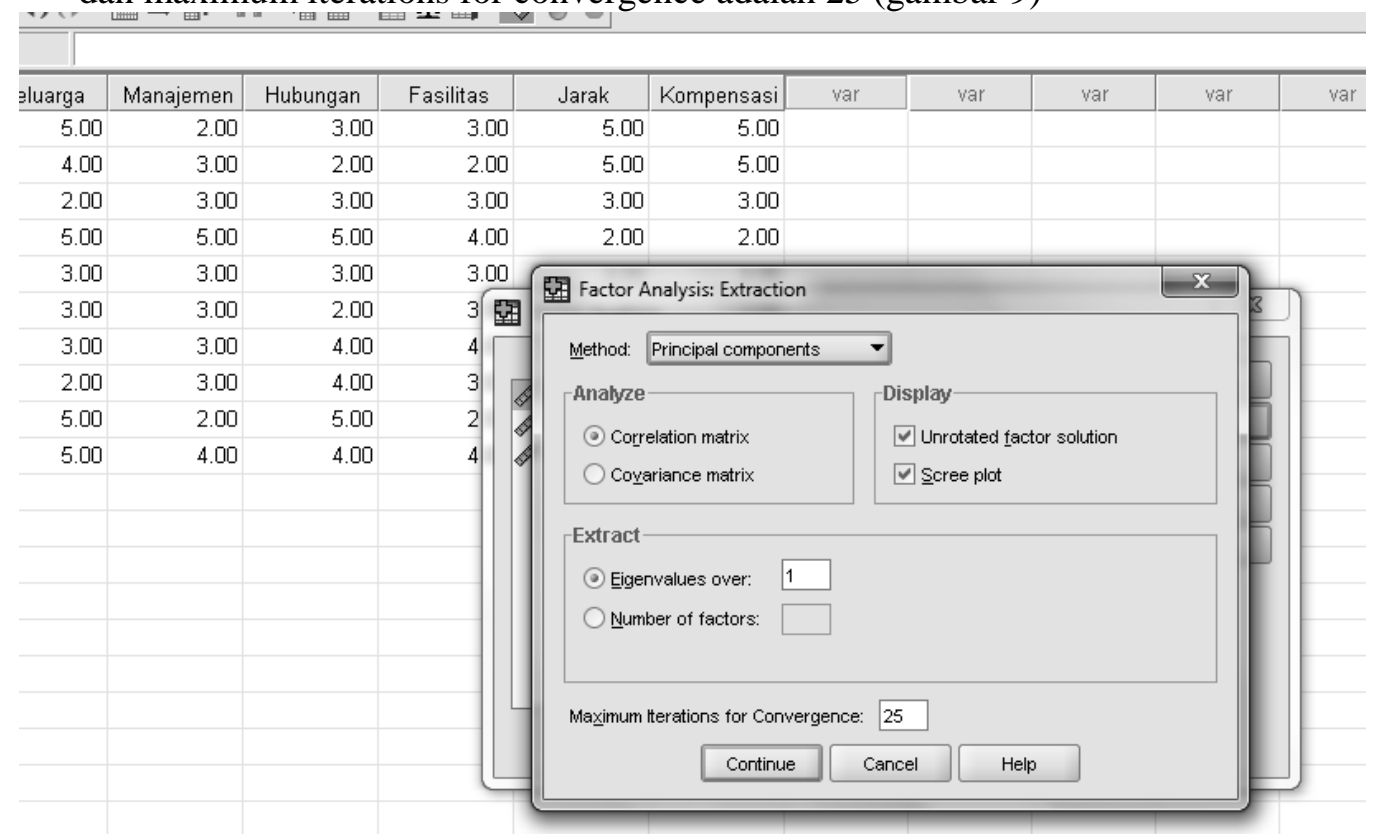

Gambar 9. Kotak Exctraction

Kemudian klik mouse pada kotak rotation dan pilih varimax dan untuk display pilih rotated solution dan loading plot (Gambar 10. Kotak Rotation)

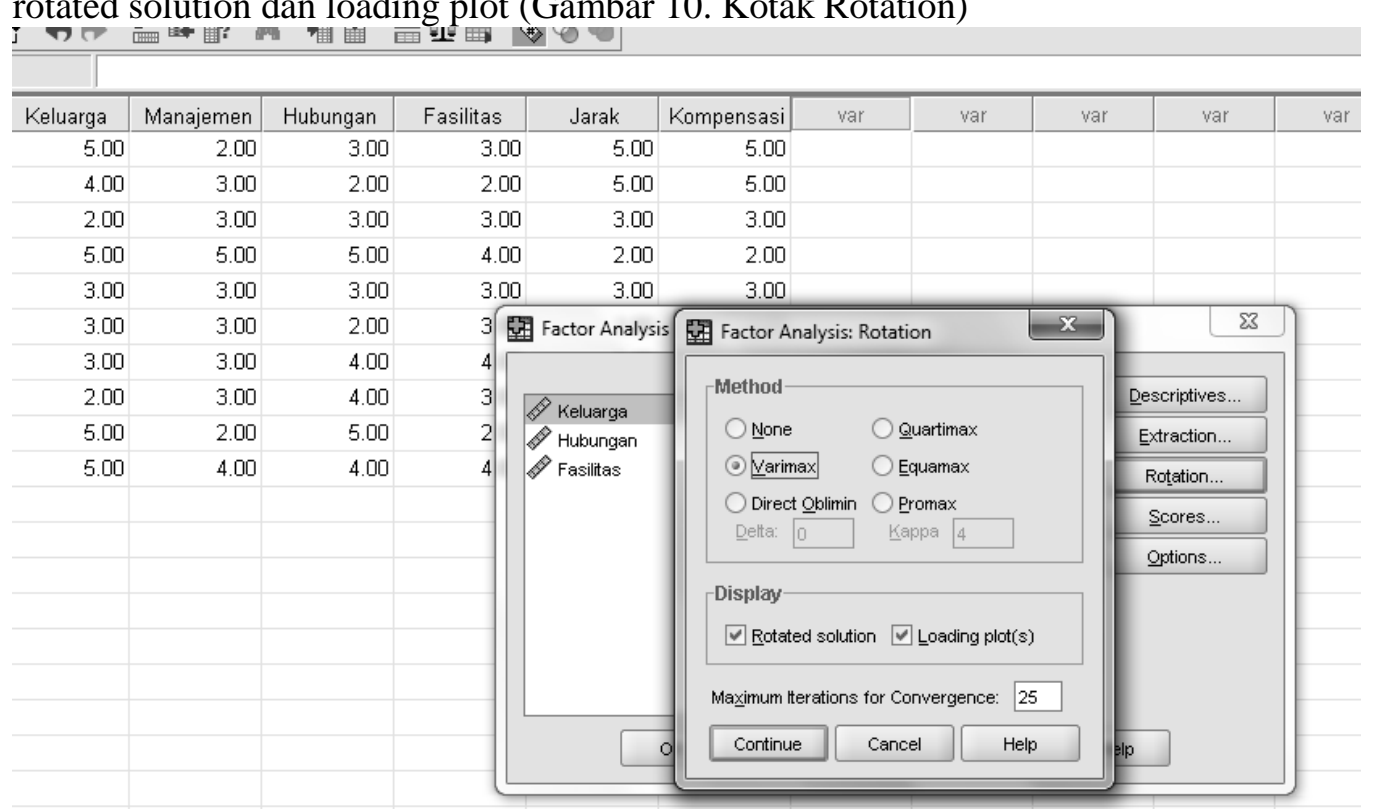

Gambar 10. Kotak Rotation 
Adapun hasil output nya terdapat communalities dimana merupakan jumlah varians (bisa dalam presentase) dari suatu variable mula-mula yang dijelaskan oleh factor yang ada. Untuk variable manajemen angka adalah 0.582 , hal ini berarti sekitar $58,2 \%$ bisa dijelaskan oleh factor yang terbentuk. Dan untuk jarak angka adalah 0.858 , hal ini berarti sekitar $85.8 \%$ bisa dijelaskan oleh factor yang terbentuk.kompensasi angka adalah 0.582 , hal ini berarti sekitar $92,6 \%$ bisa dijelaskan oleh factor yang terbentuk. (Tabel 5. Communalities)

Tabel 5. Communalities

\section{Communalities}

\begin{tabular}{|l|c|r|}
\hline & Initial & Extraction \\
\hline Manajemen & 1.000 & .582 \\
Jarak & 1.000 & .858 \\
Kompensasi & 1.000 & .926 \\
\hline
\end{tabular}

Extraction Method: Principal Component Analysis.

Untuk tabel total variance adalah untuk melihat berapa factor yang terbentuk. Adapun factor yang terbentuk berdasarkan nilai initial eigenvalues adalah satu factor, karena angka eigenvalues dibawah 1 tidak digunakan dalam menghitung jumlah factor yang terbentuk

Tabel 6. Total Variance Explained

\begin{tabular}{|c|c|c|c|c|c|c|}
\hline \multicolumn{7}{|c|}{ Total Variance Explained } \\
\hline \multirow[b]{2}{*}{ Comnonent } & \multicolumn{3}{|c|}{ Initial Eigenvalues } & \multicolumn{3}{|c|}{ Extraction Sums of Squared Loadings } \\
\hline & Total & $\%$ of Variance & Cumulative $\%$ & Total & $\%$ of Variance & Cumulative $\%$ \\
\hline 1 & 2.366 & 78.866 & 78.866 & 2.366 & 78.866 & 78.866 \\
\hline 2 & .565 & 18.818 & 97.684 & & & \\
\hline 3 & .069 & 2.316 & 100.000 & & & \\
\hline
\end{tabular}

\section{Scree Plot}

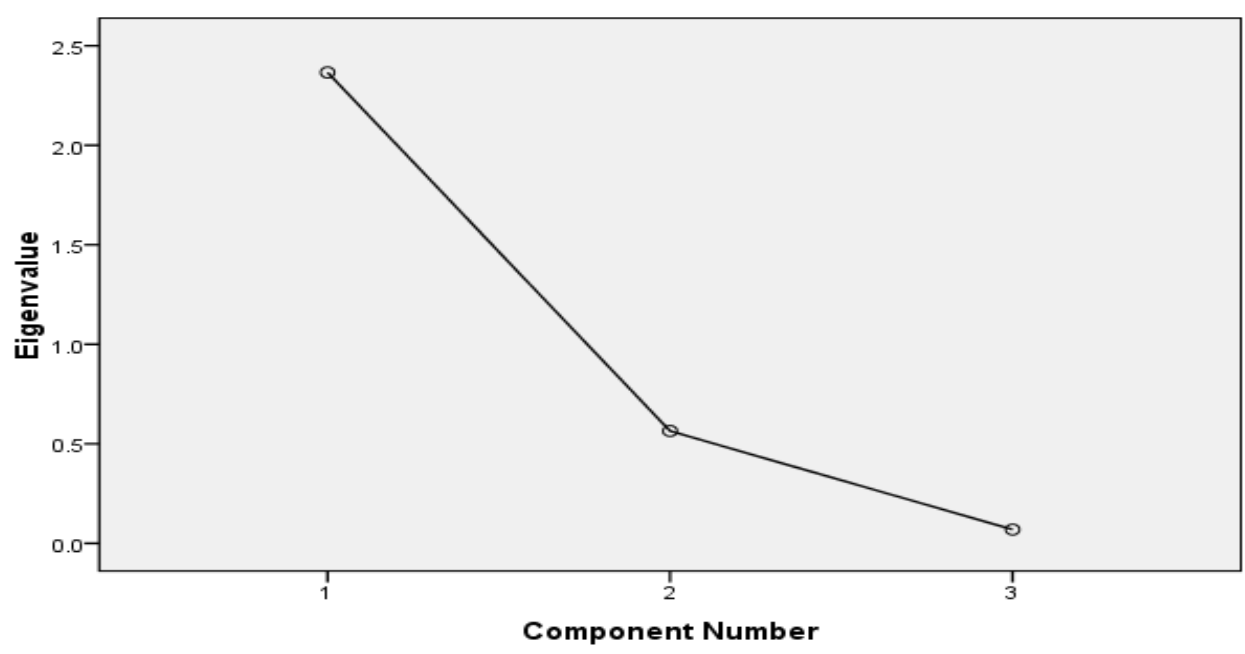

Gambar 11. Screen Plot 


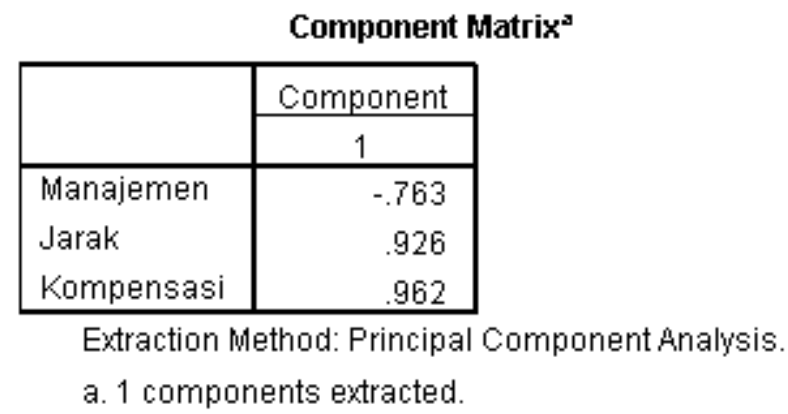

Setelah diketahui ada satu factor terbentuk maka jelas bahwa ketiga variable tersebut membentuk satu factor dimana angka-angka pada tabel component matrix adalah angka factor loading yang menunjukkan korelasi antara variable manajemen adalah - 0,763 adalah kuat walau dengan tanda -, karena hanya menunjukkan arah korelasi yang berlawanan dengan factor 1. Dimana semakin tidak adanya evaluasi dari pihak manajemen serta pemberian punishment maka dosen-dosen semakin tidak mematuhi ketentuan yang berlaku.Dan untuk variable yang kedua jarak adalah 0.926 korelasi terhadap factor 1 adalah kuat karena hasil berada di atas angka 0.5.dan untuk korelasi antara variable kompensasi dengan factor 1 adalah 0.962 , dan ini kuat. Dimana dikarenakan Kompensasi transport yang tidak sesuai dengan jarak bisa menyebabkan akan kekurangan kewajiban 25 jam/minggu.

\section{KESIMPULAN DAN SARAN}

A. Kesimpulan

1. Rata-rata keseluruan kehadiran dosen datang /minggu adalah $19,5 \mathrm{jam} / \mathrm{ming} g u$.

2. Variable variable penyebab kekurangan jam dosen datang/minggu adalah keluaraga, manajemen, hubungan social, fasilitas pengajaran, jarak/lokasi, kompensasi transport

3. Berdasarkan uji Bartley test dan Measure somple of adequate yang pertama maka dengan nilai sig 0.04 dan msa 0.540 maka ini lulus uji karena telah memenuhi syarat. Namun ada tiga variable yang harus dikeluarkan dikarenakan nilai MSA nya kurang dari 0.5 yaitu keluarga, hubungan social dan fasilitas dibawah 0.5 yaitu keluarga 0.347 hubungan 0.463 fasilitas 0.476 .

4. Untuk proses kedua yaitu variable manajemen(msa 0.733), jarak/lokasi (msa 0.565), dan kompensasi (msa 0.550) bisa dilanjutkan ke tahap untuk pembentukan factor baru karena msa $>0.5$

5. Dengan menggunakan metode principal component analysis maka pembentukan factor hanya ada 1 componen karena nilai eigen value yang mempunyai nilai diatas 1.

6. Factor pembentuk baru yaitu manajemen, kompensasi dan jarak menjadi satu component

\section{B. Saran}

1. Berdasarkan penelitian yang telah dilakukan diperoleh factor pembentuk baru terhadap alasan bagi kekurangan jam keadiran dosen selama 25 jam/minggu yaitu saran untuk manajemen diperlukan evaluasi teradap dosen-dosen yang telah memenuhi kewajiban $25 \mathrm{jam} /$ minggu ataupun yang belum memenuhi kewajiban tersebut (dengan perekapan tiap minggu dari pihak administrasi) dan adanya pemberian reward bagi yang memenuhi ataupun punishment bagi yang tidak memenuhi. 
2. Dan untuk kompensasi tunjangan transport diperlukan keadilan bagi dosen-dosen yang mempunyai rumah jauh/pengklasifikasian berdasarkan daerah, misal Jakarta Pusat, diluar Jakarta Pusat, Bekasi, Tangerang, Depok, Bogor dll tentu tidak akan sama besaran tunjangan transport daerah satu dengan yang lainnya. Disarankan untuk pihak terkait meninjau kembali kebijakan penetapan tunjangan transportasi.

\section{DAFTAR PUSTAKA}

[1] Akhmad Fahmi. 2007. Analisis Faktor-Faktor Yang Mempengaruhi Loyalitas Karyawan pada Bagian Pengemudi PT. Citra Perdana Ken Dedes Malang”. Jurnal Ekonomi Universitas Muhammadiyah Malang. 3(2) hal 112 Malang

[2] Arikunto, Suharsini. 2002. Prosedur penelitian. Bina Aksara, Jakarta

[3] Santoso, Singgih. 2004. Latihan SPSS Statistik Parametrik jakarta: Bumi Aksara.

[4] Santoso, Singgih. 2012. Aplikasi SPSS pada Statistik Multivariat : Elex Media Komputindo, Jakarta

[5] Sondang P. Siagian. 2004. Manajemen Sumber Daya Manusia. Jakarta : Bumi Aksara. 